\title{
A Sociolinguistic Study of Religious-Based Proverbs in Al-Bahah Province
}

\author{
Naimah Ahmad Alghamdi \\ Assistant Professor, College of Arts, Imam \\ Abdulrahman bin Faisal University (IAU), KSA
}

\begin{abstract}
The initial impetus for studying the dialectical scene as spoken by Ghamed and Zahran in Al-Bahah is to retain a valuable aspect of Al-Bahah province culture in "Apparent Time". The study is a contribution to the accumulating literature in sociolinguistics which addresses the issue of language use as a social and cultural representative of a particular speech community. The study reconstructs a synchronic analysis of Al-Bahah proverbs that perform certain speech act/s in different speech situations involving speakers of Al-Bahah dialect and relates these proverbial utterances to either the Holy Qur'an or the Prophetic Hadith. The study employs John Searle's (1995) theory of the "in/direct speech act/illocutionary act "applied to the linguistic analysis of 13 proverbs occurring in conversational situations among speakers who form a speech community - sharing the same
\end{abstract}

language and the same cultural background. Investigating how far the socio-linguistic values of Al-Bahah speech community is embodied in their conversations, the study finds out that their use of these proverbs reveals pragmatic fitness of the performative proverbs to the situational context. Moreover, the findings indicate that the speakers of the dialect are not detached from their authentic religious beliefs and values. Methodologically, the study offers a socio -cultural description of proverbs as employed by the urban Arabic speaking community of southern West province of Al-Bahah, Saudi Arabia. It assigns speech acts to these conversational proverbs. Finally, it relates the proverb proposition either to the Holy Qur'an or the Prophetic Hadith.

Keywords: synchronic analysis, proverbs, speech act, socio-cultural context, sociolinguistics, speech community 


\section{A Sociolinguistic Study of Religious-Based Proverbs}

\section{in Al-Bahah Province}

Naimah Ahmad Alghamdi

\section{Introduction}

Nothing defines a culture as distinctly as its language, and the element of language that best encapsulates a society's values and beliefs is its proverbs" (Martin, 2015, p.4). According to Ashipu (2013, p.10), "proverbs are circumstantial speech acts frequently used in conversations to embellish, conceal and adorn such speech". They constitute a significant part of verbal language. Like other types of folk-sayings, proverbs are considered genres of verbal communication which can be found in all languages regardless of their cultural background, urban or civilized, advanced or primitive (Abul Jabar 2008, p.11). Proverbs convey a great deal of meaning, associated with people's thoughts, habits, beliefs, experiences, traditions and patterns of life.

Proverbs evolves from traditional lore, history, and religion, and is usually attributed to elders as it is believed to contain the wisdom of the elders or ancestors in the society (Olatunji, cited in Lamidi, 2008, p.62). Norrick (1985, p.31) describes proverbs as "self-contained, pithy, traditional expressions with didactic content and fixed, poetic form". By didactic, Norrick refers to proverbs that are designed to teach people something such as moral lessons, perspective rules, advice, warning, encouragement and some truth about experience.

\subsection{Objectives of the Study}

The study is meant to tackle Al-Bahah proverbs pragmatically and textually and traces the performative nature of these proverbs in specific contexts of situations and evaluate how far AlBaha proverbs correspond either in their semantic content or the speech acts they perform to Qur'anic verse or prophetic Hadith.

\subsection{Research Questions}

The study attempts to answer the following questions:

1. How is Al-Bahah proverbs performance displayed in conversational situations?

2. How far do these dialectal proverbs contribute to unveil the social and cultural life of Al-Bahah speech community?

3. How far is the Islamic thought rooted in Al-Bahah proverbs?

\subsection{Limitations of the Study}

The study is limited to the proverbs spoken by the urban southern west community of Al-Bahah. The subjects of the study are men and women who belong to Al-Bahah speech community 'originally from Ghamed or Zahran ', their age ranges from 47 years old and above. The data collected for the study is obtained through observation, audio recording, taking notes, and interviews. Thirteen proverbs were chosen from the collected proverbial conversations. For the present study, the context of situation is the environment in which the proverb becomes meaningful. Context of Al-Bahah Culture is not explored unless it bears a specific interpretation to the proverbs. It is also limited to the linguistic analysis of the llocutionary and illocutionary acts of the proverbs impeded in conversational situations among speakers of the dialect. The illocutionary function of the 
proverbial speech act is beyond the scope of the study. The study assigns the proverbs under investigation to conceivable corresponding verses of Holy Qur'an or prophetic Hadith that emphasize the semantic content or the performativity of the proverb. It does not tackle the metaphorical aspect of the proverb unless it is necessary for the explication of its meaning in relation to Al-Bahah speech community; otherwise it is not explored.

\subsection{Operational Definitions}

In this section, certain terms that are central to the study are clarified (e.g. AlBahah dialect, speech acts, Al- Bahah speech community and the socio- cultural context of proverbs). The present study does not attempt a definition of dialect as it is a complex and often a misunderstood concept. For the purpose of the present study, dialect is defined as the spoken variety used in a speech community whereas Al-Bahah dialect is defined as the collection of attitudes (e.g., phonological, syntactic, morphological, lexical and semantic) that make one group of speakers noticeably different from another group of speakers of the same language (Fairlough, 1992, p.6). In the Southern West Province of Saudi Arabia, Arabic dialect of belad Ghamed and Zahran (Al-Bahah dialect) is the standard variety of the regional varieties (Nadwi 1968, p. 10).

For the purposes of the present study, speech acts (henceforth SAT). are defined as proverbial utterances that occur in a sequence of natural conversations between speakers of Al-Bahah dialect. However, the notion of speech acts, as Blum-Kulka et al in Al-Sohaibani $(2017$, p. 70$)$ noted, is "one of the compelling notions in the study of language use ". This is due to the extensive social, cultural and religious implications a speech act involves. The study is confined to the investigation of the locutionary speech acts communicated in proverbs that occur in a conversational situation; when a speaker performs an utterance (locution, which the proverb direct meaning). Besides, the study accounts for the illocutionary speech act which is the performance of the act of saying something with a specific speakers' intention (the indirect meaning). The study presents the situation of the speech activity as communicated between the participants contextually and by reference to speakers' turns in the speech event. Investigating Al-Bahah proverbs in current socio-cultural contexts that expose how Al-Bahah speech community conceptualizes these proverbs that are weighted not only with social and cultural implications but also with religious ones. The socio-cultural context of a proverb poses a problem, as Ramirez (2015, p.22) states:

Proverbs do not boost an independent existence, as say the tale form. This simply means that the proverb has no life of its own, it only comes alive when it is "performed" as part of a wider context, especially that of discourse.

The apparent time hypothesis has proven highly productive in the analysis of the proverbial scene in correlation to sociolinguistic approaches (Wardhaugh, 2002). This is what Labov (1972) refers to as a "dynamic dimension" to synchronic description of language use, so that the past helps to explain the present and the present helps to explain the past. The employment of Al-Bahah proverbs in natural occurring conversations interconnects the past to the present. AlBahah speech community compromises homogeneous tribes of rural, urban and tahamah inhabitants connected by their unique cultural values 'including religious ones'. Religious practices, beliefs and conducts pertain to every aspect of life. Al-Sohaibani (2017, p.14) comments that "the influence of religion in Saudi daily life makes it probable that this omnipresence could have a religious foundation". 
In Al-Bahah proverbs are used in interactions to enrich a speech and achieve greater force and communicate a thought. They are a discourse which has its own subject matter, participants and speech events. In all these occurrences, the emphasis is on the context of situation: the context makes the meaning of a proverb comes to life.

\subsection{Sources of the Data and Methodology of the Study}

The study is observational in essence and employed different techniques for the collection and verification of Al-Bahah proverbs. The primary data of the study is a collection of Al-Bahah proverbs embedded in natural conversations among speakers of Al-Bahah dialect. For the verification of the of proverbs' originality in relation to Al-Bahah dialect and thematic classification, the study benefited from the comprehensive secondary source of Ali Alsalouk (1994) (Almawrouthat Alsh'beiyah le Ghamed wa Zahran), the Fifth series of Al Amthal (literally an example and Alhikam (literally wisdom) .The author of the book collected AlBahah proverbs through note taking as he was in close contact with Al-Bahah local community due to the nature of his administrative work in Al-Bahah Emirate. Proverbs that do not belong to Al-Bahah speech community were excluded.

The subjects of the study are men and women who belong to Al-Bahah speech community 'originally from Ghamed or Zahran ', their age ranges from 47 and above years old. The data collected for the study is obtained through observation, audio recording, taking notes, and interviews. Four female informants who speak Al-Bahah dialect helped in the data collection. The researcher was not present during the conversations and instructions were given to the informants to notify the subjects involved in conversational events that tape recording is taking place. Since most of the subjects were close friends and relatives of the study informants, consent of recording was not an issue .The researcher investigated 13 proverbs of AlBahah speech community against the secondary reference of the data and proverbs of different origins "due to various language contact situations "were disregarded .The descriptive analysis of the proverbs utilized by speakers was carried following a linguistic approach that fits the theoretical tools of the study.

In fact, a qualitative approach as a trend towards the description and explanation of language use as exploited by its speakers is outstandingly successful in revealing the linguistic and nonlinguistic factors which underpin language use (Trask 1996, 1999 and Mesthrie, 2001). Since the present study relies heavily on natural occurring contexts of proverbs, the researcher finds it necessary to employ a diversity of methods for collecting data known as 'triangulation' in sociolinguistics (Johnstonein Mesthrie, 2001, p.325), namely participantsobservation, observation and interviewing.

Participant-observation has been important in quantitative as well as qualitative sociolinguistic work and is the primary research technique of the ethnography of communication( Johnstone, 2000). The researcher as a member of the speaking community plays the role of the participant-observer (saville-troike, 1989).Being a member of the Al-Bahah community, enables the researcher to utilize this method on a daily basis especially in taking an active role in some real situations recorded in the study. The role entails observing routine activities of different types of individuals, men and women, younger and older people, in the domains of domestic and social gathering, and growing sensitivity to implications of the context and sequencing Note-taking proves to be useful for recording what actually happens and provides an accurate basis for the analysis. 
Observation without taking an active part in the actual interaction is employed whenever it is appropriate. Taking-note is also activated, and it is mainly a record of the situation. It is important to note that the researcher save no effort to be participant-observer in one time and sometimes as an observer during the same social gathering or meeting with the community members. As for interviewing, only a small portion of the data is collected through the traditional sociolinguistic method named interviewing. It consists mainly of the following questions:

(a) When the proverb (...) is used?

(b) To whom is it directed?

(c)Why is it used?

\subsubsection{The Ethnography of Speaking: Units of Analysis}

The most central concern of the Ethnography of speaking is the description of speech situation, speech event and speech act. The present study observes the three units as equivalent conceptualization of Searle's context, scene or event and speech act, within which the analysis of the proverbs is formulated. The relationship between the three units of analysis can be illustrated as follows: $a$ speech situation is the context wherein communication occurs. A speech event as stated by Hymes (1991, p.52) ' the term' event' is used to designate a culturally defined, bounded, segment of the flow of behavior and experience constituting a meaningful context for action", e.g. a party is a speech situation and the conversation at the party is a speech event). Communicative acts are contextshaped of intertextual assumptions that associate message forms with social meanings "(Philipsen in Mesthrie, 2001, p.145), are all interacting in a single event.

\subsubsection{Data Analysis}

As stated earlier, the corpus of the study is a collection of Al-Bahah proverbs embedded in natural speech situations. The analysis of each proverb comprises the following five steps:

(a)the proverb is introduced in the source text (Arabic) and a target text (English)

(b)the event (scene) of the proverb is translated to English

(c)the proverb context of situation is narrated and linked to the theoretical framework of the study

(d) illocutionary act of the proverb utterance (direct/indirect) and proverb structure (simple / complex) are highlighted in relation to the speech situation recorded.

(e) the related Qur'an verse or Prophetic Hadith that endorse performativity of the proverb or its semantic content is suggested, documented in Arabic and English, and its semantic explanation from Tafsir ibn Kathir (for Qur'anic verses), and the authentic clarification and explanation of the Ibn Al-Qyyim(2010) and Alnawawi' Riyad Al-Saleheen (2003) ( for Prophetic Hadith ) are provided. Authentication of Hadith by providing scriptural authority from Sahih "authentic" was not an easy task. While the numbers of verses pertaining to the semantic proposition or performativity of the proverb are few, reference to the literature of hadith was sufficient enough to cover the semantic contents of the proverb. This is comprehensible as hadith is a detailed bulk of the Islamic law. The first four steps address the research question of how far do these dialectal proverbs contribute to unveil the sociolinguistic beliefs and values of AlBahah proverbs regarding their illocutionary acts. The fifth step answers the third research question of how far Islamic concepts are rooted in Al-Bahah proverbs. 
Arabic Symbols used in transcription (Adopted from Holes, 1984)

\begin{tabular}{|c|c|}
\hline \multicolumn{2}{|c|}{ Consonants } \\
\hline /?/ a voiceless glottal plosive & $\begin{array}{l}/ \delta / \text { a voiced denti-alveolar emphatic } \\
\text { fricative }\end{array}$ \\
\hline /b/ a voiced bilabial plosive & /c/ a voiced pharyngeal fricative \\
\hline $\begin{array}{l}\text { /t/ a voiceless denti-alveolar non-emphatic } \\
\text { plosive }\end{array}$ & /G/ a voiced uvular fricative \\
\hline$/ \theta /$ a voiceless dental fricative & /f/a voiceless labio-dental \\
\hline$/ \mathrm{j} /$ a voiced palatal affricate & /q/a voiced velar plosive \\
\hline /H/ a voiceless pharyngeal fricative & $/ \mathrm{k} / \mathrm{a}$ voiceless velar plosive \\
\hline /X/ a voiceless uvular fricative & /1/ a voiced alveolar lateral \\
\hline $\begin{array}{l}\text { /d/ a voiced denti-alveolar non-emphatic } \\
\text { plosive }\end{array}$ & $/ \mathrm{m} / \mathrm{a}$ voiced bilabial nasal \\
\hline$/ \delta / a$ voiced dental fricative & /n/ a voiced alveolar nasal \\
\hline$/ \mathrm{r} /$ a voiced alveolar flap & $/ \mathrm{h} /$ a voiceless glottal fricative \\
\hline /J/ a voiceless palatal fricative & /w/ a voiced labio-velar semi-vowel \\
\hline /S/ a voiced alveolar emphatic fricative & /y/ a voiced palatal semi-vowel \\
\hline $\begin{array}{l}\text { /D/ a voiced denti-alveolar emphatic } \\
\text { plosive }\end{array}$ & $\begin{array}{l}/ \mathrm{s} / \text { a voiceless alveolar non-emphatic } \\
\text { fricative }\end{array}$ \\
\hline $\begin{array}{l}\mathrm{T} / \text { a voiceless denti-alveolar emphatic } \\
\text { plosive }\end{array}$ & $\begin{array}{l}\text { /z/a voiced alveolar non-emphatic } \\
\text { fricative }\end{array}$ \\
\hline
\end{tabular}




\begin{tabular}{|c|c|}
\hline Short Vowels & Long Vowels \\
\hline /i/ high front unrounded & $/ \mathrm{i}: /$ high front unrounded \\
\hline$/ \mathrm{a} /$ low central unrounded & /a:/ low central unrounded \\
\hline$/ \mathrm{u} /$ high back rounded & $/ \mathrm{u}: /$ high back rounded \\
\hline
\end{tabular}

\subsection{Literature Review}

Proverbs have been the subject of interest from different perspectives; linguistic, educational, social, psychological, anthropological, etc. Linguistically speaking, the majority of scholarships focus on the structural features of proverb texts. Yet, there are considerable bodies of studies investigating proverbs in relation to social and cultural domains especially in the African context. Significant research in the oral tradition of African proverbs especially Yoruba proverbs have been studied, reviewed and translated into English like the eminent studies of Oyekan Owomoyela (2005). (Ayinuola and Edwin, 2014 and Melefaand Chukwumezie, 2014).

In recent years, scholars have begun to investigate Speech Acts by identifying certain poetic and structural features that appear frequently in proverbs and which constitute, in very broad terms, the concept of proverbial style or what Shirley Arora in Coinnigh (2015 p.113) has termed proverbiality. These devices are" parallelism, ellipsis, alliteration, rhyme, metaphor, personification, paradox and hyperbole that occur frequently in proverbs across languages and may be termed proverbial markers"(p.113)

Ramirez (2014) pragmatically analyzes the functions and uses of proverbs taking examples from English and Spanish proverbs. He applied Sperber and Wilson's Relevant Theory to explain how proverbs allow the speaker to express his/her intention in an implicit way. The findings demonstrate that the main functions of proverbs are criticism, advice and warning. Abdul-Jabbar's (2008) applies Speech Acts theory to conversational English proverbs at a pragmatic, Semantic and structural levels and concludes that the speech act of advice is mostly used implicitly to achieve politeness.

Ashipu (2013) article on Proverbs are circumstantial speech acts posits that for effective understanding of language use (African oral literature) in traditional societies, proverbs should be incorporated into the study of applied linguistics which compromises Discourse Analysis, Pragmatics, Semantics, Sociolinguistics and Stylistics of African folk languages. Al-Sa'adi (2009) applied a socio-cultural perspective to Makkan Proverbs applying Searle's Speech Acts Theory. The study concludes that urban Makkan proverbs foreground culturally speaking (qualitatively and quantitatively) specific themes mostly related to assertive (mainly direct speech acts) and directive (mostly indirect speech acts) good conduct and misbehaviors.

Leech $(1989$, p. 20) proposes a model for speech acts recognition that takes into consideration the nature of human communication. He argues for a 
complementary approach that takes into consideration the conventional meaning of the words and the contextual interpretation being accommodated. While theorization is appealing, yet in practice Leech did not solve the problem of which meaning should take priority in the interpretation of an utterance. Coinnigh (2015) provides a comprehensive guide to structural and semantic functions of English and Arabic proverbs.

Jinadu (2015) study of Arabic and Yoruba proverbs aims to uncover some universal cognitive stereotypes assumed in the (de)construction of proverbial discourse(s) of Arabic and Yoruba speakers, and essays exposing shared elements of intertextuality discoverable from Arabic and Yoruba proverbs. The contribution of this article lies in its practical display of some Arabic and Yoruba proverbial texts intended to reflect how the two natives (inter) textualize their socio-cultural experiences. Scholars also have studied proverbs from a stylistic and structural perspective. They identified a range of devices which operate in ensemble to affect the concept of proverbial style, amongst which the most important are parallelism, ellipsis, alliteration, rhyme, metaphor, personification, paradox, and hyperbole (Mieder 2004, 7).

Within the frame of Austin's theory of illocutionary acts, Lawal et al. (1997) analyzes contradictory pairs of Yoruba proverbs. They conclude that the direct illocutionary force of most Yoruba proverbs tends to be mainly assertive. Whereas a small amount of the proverbs are commissure. The study also emphasizes the importance of employing different types of pragmatic context to interpret proverbs appropriately and to resolve the overt contradiction in each of the six selected pairs of proverbs.
The present study opts for previewing the proverbial scene of Al-Bahah, which records the cultural values of this speech community, and assigns these performative dialectal proverbs to the related speech acts of Qur'anic verse or Prophetic Hadith.

\subsubsection{Theoretical framework of Speech Act Theory and Proverbs as Pragmatic Interactions}

The theoretical framework the study has adopted is John Searle's (1995) theory of "indirect speech acts" and "taxonomy of illocutionary acts". His assumptions of direct and indirect act are also adopted. The study presented a sociolinguistic analysis of Al-Bahah proverbial discourse to reveal the types of direct and indirect speech acts employed in religious-oriented proverbs; 13 proverbs occurring in conversational situations of the assigned speech community are investigated.

\subsubsection{Proverbs as Speech Acts}

Proverbs allow a given speaker from a speech community "to communicate an idea or beliefs using a fixed phrase in the appropriate context "(Ayeni in Ramirez (2015, p.4). Speech acts are acts of communicating something to an audience. Speech acts which people simultaneously perform when communicating an utterance are classified into locutionary, illocutionay and perlocutionary acts (Austin 1962, Searle 1979, Thomas1995, Oishi 2006, Ashipu 2013, Connigh 2014, Jinadu 2017). Searle (1979, p.16) states that "all linguistic communication involves linguistic speech acts, they are the basic or the minimal units of linguistic communication and to decode the whole utterance and its proper meaning, context has to be understood ". Searle (1979, p.17) describes indirect speech acts as follows: "in indirect speech acts, the speaker communicates to the hearer more than he 
actually says by way of relying on their mutually shared background information, both linguistic and nonlinguistic, together with the general powers of rationality and inference on the part of the hearer." According to Searle, speech acts are grouped into five types: Assertives, Directives, Commissives, Expressives, and Declaratives (p. 18).

Many attempts have been made to develop, systemize, revolutionize Austin' Speech Acts Theory.Austin (1962), Brown and Levinson (1987) and Leech (1980) theoretical models debated over the parameters for accounting for the classification and categorization of SA and how to account for a speaker's intention in an utterance, and 'blur the distinction between utterances that report already accomplished acts and those that bring reportable acts to life' like proverbs, (Adeeko, 2016,p.42). The main attack for the theories of SA is trying to solve the problem of identifying a speech act in a discourse without looking at the problem as a whole which is how to communicate effectively relying on the immediate context, speech event and the cultural context. The present study focuses on illocutionary acts as communicated culturally in Al-Bahah speech community and adopts Searle's alternative taxonomy (1979) to determine the illocutionary act of the proverbs under investigation. Moreover, the study takes into consideration the context of the speech situation and speech event in which the proverbial utterance occurs together with the wider context of Al-Bahah culture.

\subsubsection{Direct Speech Acts versus Indirect Speech Acts}

Based on Searle's (1979) assumption that an indirect speech act has two illocutionary forces, one literal or direct and the other non-literal or indirect, the present study identifies both the direct and the indirect speech acts of the proverbs used in the conversations. While the literal or direct speech act is secondary, the nonliteral or indirect is primary. Searle's account of how to work out the meaning of indirect speech act is to get from what is said to what is meant. He assumes that in indirect speech acts, the speaker communicates to the hearer more than what he actually says by way of relying on their mutually shared background information; the ability of the hearer to make some kind of inference and conventionality. In short, the direct act is the point of departure leading to the indirect act (Searle, 1979, Thomas, 1995, Geis, 1995, Mey, 2001).

Another approach to the analysis of indirect speech act is the structural approach. The grammatical forms of a speech act whether declarative, interrogative and imperative interfere with the speaker' level of in/directness. If there is a direct match between a sentence type and an illocutionary force; we have a direct speech act. On the other hand, if there is no direct relationship between a sentence type and an illocutionary force, we have an indirect speech act (Geis 1995, Thomas 1995, Mey 2001). Searle's model of speech acts applies to metaphorical and non-metaphorical language use. In case of non-metaphoric proverbs, the speaker means what he says and he/she can also mean something more; in case of a metaphoric proverb in which the speaker means what he does not actually say. Searle (1979) makes a distinction between the literal meaning, which he calls word or sentence meaning, and metaphorical meaning, which he calls the speaker's utterance meaning. Accordingly, the employment of metaphor is a device to perform certain indirect speech acts.

Searle's approach and the structural approach of the analysis of indirect speech 
acts are fused for the sake of the study. Methodologically, the study starts with the proverb original text (Arabic) and the target text (English), moves to the actual speech event, then to the context of situation, and finally to identify the illocutionary act (both the direct and indirect act).Within these tabulated units of analysis, the relation of the proverb to religion is maintained through assigning the proverb to the related Qur'anic verses or prophetic hadith.

\subsubsection{Proverbs and the Pragmatics of Al-Bahah Conversational Interactions}

Proverbs of popular wisdom abound in Al-Bahah dialect to accentuate and highlight discourses in given context. These expressions of wisdom are usually referred to as proverbs (Ayeni, 2011, p.4). Speakers of Al-Bahah dialect, especially the old people cannot communicate effectively on many occasions without marking their conversations with proverbs. Being Muslims, the people of Al-Bahah quote in their daily interactions positive views concerning issues such as belief, family life, adhering to morals and abandoning misdeeds that originally spring from true religious principles. They advocate them not only theoretically speaking but also practically through enclosing these proverbs in daily interactional conversations. By quoting a proverb to fit in the conversational proposition in a speech situation, the cultural context of the past is operative. For the present study, contexts involve more than the natural occurring conversation in which the proverb occurs; context is the cultural sense of the proverb plus the situational context it functions in.

\subsubsection{Demography and Histomography of Al-Bahah Province}

In this section, a general outlook of the historical, geographical and demographical situations of Al-Bahah Province is discussed with particular reference to AlBahah dialect or what is known as lahjat ghamed wa Zahran (the dialect of Ghamed and Zahran). In fact, a review of these heterogeneous sources that play a great role in forming the speech community at Al-Bahah Province is significant and necessary for the subsequent analysis of Al-Bahah proverbs. Ingham (1982) attempted a classification of Arabic dialects in Saudi Arabia. He categorized four dialectal groups: (1) the North-west dialects, (2) the South-west Arabian dialects, (3), the Hijazi dialects, and (4), the North-East Arabian dialects (spoken by large tribes in Najd). The Anazi dialect includes dialects of the Gulf countries and some of the north Bedouin dialects.

The kingdom of Saudi Arabia has 13 distinct regions for administrative purposes, of which Al-Bahah is located in the southern west region. Geographically, the districts of Western Saudi Arabia known as Belad Ghamid and Zahrn are located in the highlands of southern Hejaz, reaching from lt. The area is marked by the chain of mountains known as' alaqabat'. The regions of Ghamid and Zahran lie in a location of relative isolation; they lie midway on or rather near to the Taif-Abha road (Nadawi 1968, 1). The region is situated in an area characterized by rich plant cover and agricultural plateaus.

From a historical point of view, the linguistic development of the vernacular forms of Arabic is controversial. It is claimed by some Arab authors that the dialect of Belad Ghamid and Zahran (Now known as Al Baha province in SA) is nearest to classical Arabic. Ahmad Abdul ghafur aTTar ( 1942) said in an article that the language of the Hejaz (Lahjat AlHejaz), especially that which is spoken in Belad Ghamdi and Zahran is close to the Classical Language( Nadawi 1968:1). 
Proverb Situation (1)

\begin{tabular}{|c|c|}
\hline Source T & $\begin{array}{l}\text { العجلة ما تصيد الحجلة } \\
\text { (?lcajalh " haste " ma: tSe:d " never catch" ?1Hajalh "bird } \\
\text { species" ), Al-Hajala is a unique bird in the Southern -west of SA } \\
\text {,known to be swiftly fast) }\end{array}$ \\
\hline Target $\mathrm{T}$ & Haste and rush are never the way to catch a bird \\
\hline Scene & $\begin{array}{l}\text { At the sea shore: The father is teaching his Son how to catch fish } \\
\text { by using a hook. } \\
\text { Father: hold the hook and throw it in the sea and wait. } \\
\text { Son: I did, dad, and I am bored sitting and waiting and no catch. } \\
\text { Father: son! Don't worry you will eventually come to know son, } \\
\text { haste is from Satan, (al'ajalah ma: tSe:d ?IHajalah), be patient. } \\
\text { Son: got you, I will. }\end{array}$ \\
\hline $\begin{array}{l}\text { Context of } \\
\text { situation }\end{array}$ & $\begin{array}{l}\text { Domestic family speech situation. The father is teaching his son } \\
\text { how to catch fish, and his son is anxious to catch the fish but lost } \\
\text { his patience over the procedures of throwing the hook and waiting. } \\
\text { Finally, he gets annoyed. the father is implicitly trying to reverse } \\
\text { the situation with a didactic assertive statement that" haste is not } \\
\text { the way to catch a bird", and that haste is from Satan, by quoting } \\
\text { the proverb, the father is pragmatically drawing on a proverb that } \\
\text { fits the context. The proverb expresses a socio-cultural universal } \\
\text { truth that "haste makes waste" and implicitly calls for patience and } \\
\text { perseverance, assuming an understanding from his son of the } \\
\text { shared knowledge of 'haste makes waste'. The proverb and the } \\
\text { Hadith share the assertiveness of the direct SA. }\end{array}$ \\
\hline Illocutionary Act & $\begin{array}{l}\text { Direct: Asserting } \\
\text { Indirect: Supporting / Affirming } \\
\text { Type of sentence and verb: Declarative -Active } \\
\text { Complexity of structure: Simple }\end{array}$ \\
\hline $\begin{array}{l}\text { The Related Qur'an } \\
\text { Verse }\end{array}$ & 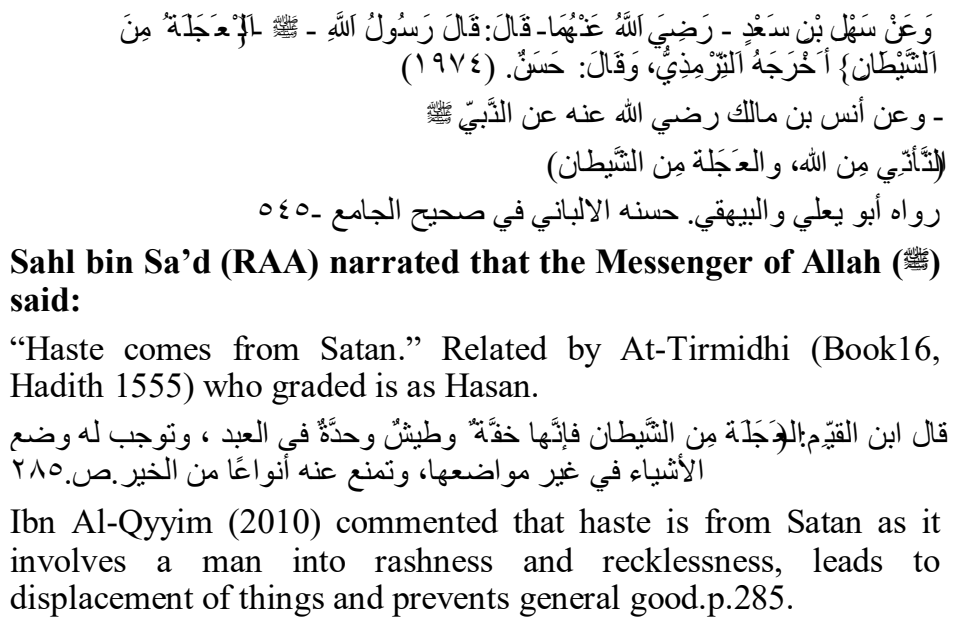 \\
\hline
\end{tabular}




\section{Proverb Situation (2)}

\begin{tabular}{|c|c|}
\hline Source T & $\begin{array}{l}\text { كلمة مدري ترفع قدري } \\
\text { (kelmat midri: " the word" I do not know" tarfac qadri:" rises my } \\
\text { position") }\end{array}$ \\
\hline Target $\mathrm{T}$ & $\begin{array}{l}\text { The proverb (the word "I don't know" elevates me, meaning saves me", } \\
\text { articulates the English meaning that "Unspoken words never does harm } \\
\text { " " silence is Golden "and "Speech is Great but Silence is Greater". }\end{array}$ \\
\hline Scene & $\begin{array}{l}\text { The speech situation is between two sisters, ready to go to a family } \\
\text { gathering. } \\
\text { The big sister: Sis, certainly they will ask you, where are you planning } \\
\text { this Summer vacation? Simply say " I don't know", no need to remind } \\
\text { you that 'the word I do not know, saves you. } \\
\text { Young Sister: It doesn't concern them, got you. }\end{array}$ \\
\hline $\begin{array}{l}\text { Context of } \\
\text { situation }\end{array}$ & $\begin{array}{l}\text { Family speech situation. The big sister quotes this proverb to motivate } \\
\text { and directs her young sister to keep silent, control her tongue and not to } \\
\text { involve others in their personal affairs. Her sister speech turns confirms } \\
\text { mutual understanding and communication of the proverb content. } \\
\text { Silence is motivated in Islam didactics 'speak well or else keep silent ', } \\
\text { and interfering in others's business is no good at all. The proverb records } \\
\text { the mother clear observation of the cultural content of the proverb when } \\
\text { she invites it into the speech event. Plenty of Hadith stresses the } \\
\text { semantic proposition and an identical performativity of the proverb' } \\
\text { indirect act as cited below. }\end{array}$ \\
\hline $\begin{array}{l}\text { Illocutionary } \\
\text { Act }\end{array}$ & $\begin{array}{l}\text { Direct: Assertive } \\
\text { Indirect: Directive, motivating } \\
\text { Type of sentence and verb: Declarative -Active } \\
\text { Complexity of structure: Simple }\end{array}$ \\
\hline $\begin{array}{l}\text { The related } \\
\text { Prophetic } \\
\text { Hadith }\end{array}$ & 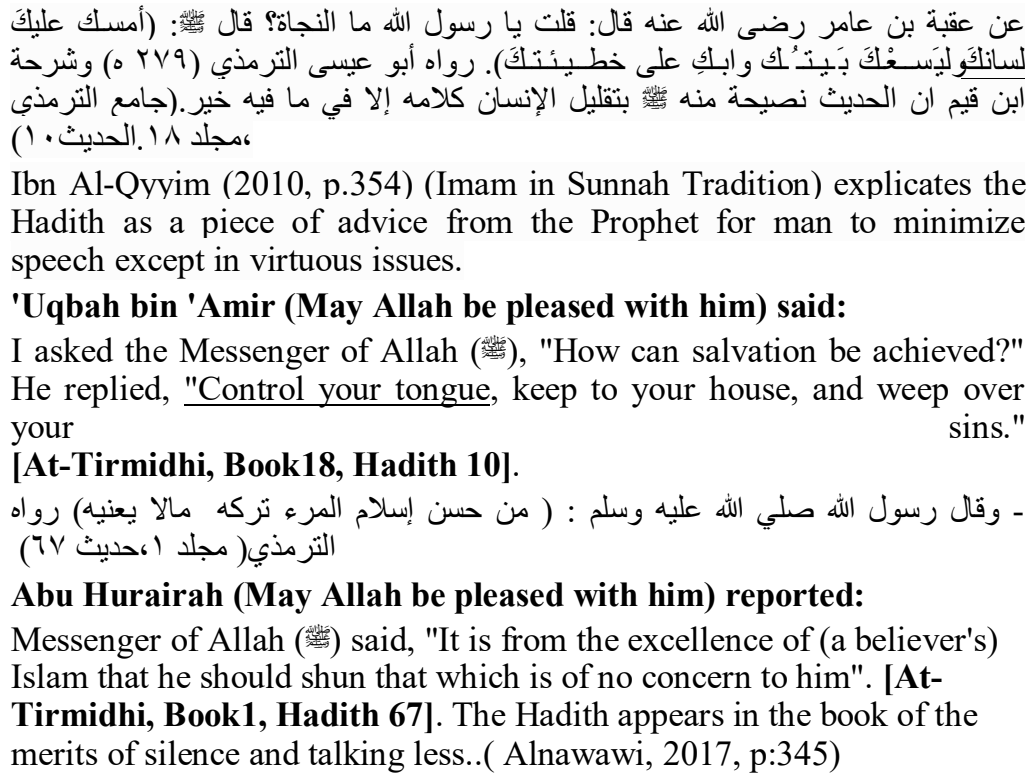 \\
\hline
\end{tabular}




\section{Proverb Situation (3)}

\begin{tabular}{|c|c|}
\hline Source T & $\begin{array}{l}\text { اللعب من رزتته } \\
\text { (?lcb " dancing" mn raztu: " from its perfect beginning ") } \\
\text { In Al-Bahah cultural context, "?lcb " is a popular traditional dance. } \\
\text { The proverb literally communicates that dancing can easily be } \\
\text { judged by its perfect beginning. }\end{array}$ \\
\hline Target $\mathrm{T}$ & $\begin{array}{l}\text { The proverb communicates the English equivalence of "Successful } \\
\text { beginnings brings about successful endings", or " a book is judged } \\
\text { by its title" and "All that is well, ends well". Perfection can be } \\
\text { estimated right from the beginning }\end{array}$ \\
\hline Scene & $\begin{array}{l}\text { In the living room, mid nigh, a mother and her daughter are } \\
\text { watching a movie. } \\
\text { The daughter: Mum, pray for me to get the job tomorrow. } \\
\text { The mother: I'm praying for you always dear, but You should be } \\
\text { sleeping by now if you want to do well in the interview y, haven't } \\
\text { you heard that ?lcb mn raztu: . }\end{array}$ \\
\hline $\begin{array}{r}\text { Context of } \\
\text { situation }\end{array}$ & $\begin{array}{l}\text { Home context of situation. The mother quotes the proverb stating } \\
\text { that one can judge things from its beginnings, as she criticizes the } \\
\text { attitude of her daughter who is still awake although she has to } \\
\text { wake up for the job interview in the morning, the proverb is } \\
\text { implicitly a serious disapproval and criticism of the daughter's } \\
\text { behavior as 'perfect starts brings about perfect ends' . The mother is } \\
\text { assertively acknowledging her daughter. The proverb context of } \\
\text { use is authenticated with reference to the study' secondary source, } \\
\text { it refers to traditional dance and the semantic content is broadened } \\
\text { to entail early judgments of any human behavior and that good } \\
\text { starts bring about good ends. The mother indirectly expresses her } \\
\text { criticism by using the proverb that directly relates to the semantic } \\
\text { content of the proverb and the direct assertive illocutionary SA. } \\
\text { The proverb and Hadith provided communicate the same semantic } \\
\text { content of motivating perfection. }\end{array}$ \\
\hline Illocutionary act & $\begin{array}{l}\text { Direct: Assertive (stating) } \\
\text { Indirect: Expressive (Criticizing and disapproving) } \\
\text { Type of sentence and verb: Declarative -Active } \\
\text { Complexity of structure: simple }\end{array}$ \\
\hline $\begin{array}{r}\text { The related } \\
\text { Prophetic Hadith }\end{array}$ & 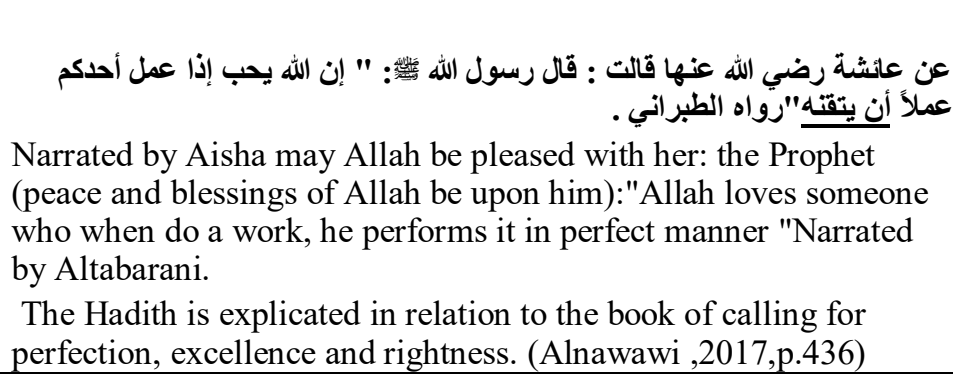 \\
\hline
\end{tabular}


Journal of English and comparative Studies

\section{Proverb Situation (4)}

\begin{tabular}{|c|c|}
\hline Source $\mathrm{T}$ & 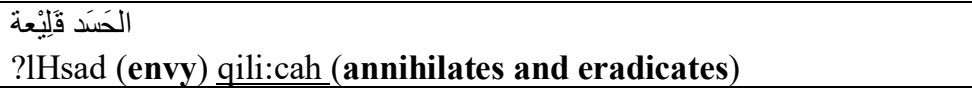 \\
\hline Target $\mathrm{T}$ & $\begin{array}{l}\text { The proverbs articulates that" envy annihilates and completely } \\
\text { destroys a person who feels envy toward others". The proverb can } \\
\text { be have the English sense "Envy consumes itself" }\end{array}$ \\
\hline Scene & $\begin{array}{l}\text { A daughter is having a conversation with her mother. } \\
\text { The Daughter: Mum, do you remember the dress I wore last night in } \\
\text { the wedding party? } \\
\text { The Mother: Yes, what's wrong with it? } \\
\text { The Daughter: Actually, I don't know! I was astonished to see it } \\
\text { ripped apart bottom, the lace is dangling, what shall I do? } \\
\text { The Mother: In the name of Allah, the Merciful the } \\
\text { Compassionate, where they will escape from Allah(His punishment } \\
\text { )! Surely, ?IHasad qili:cah, you looked good in that dress last night, } \\
\text { thanks God evil eyes fallen over the dress and not you, you better } \\
\text { get rid of that dress for good. } \\
\text { The Daughter: (Wa min Jar Hasidin ?da Hasad)"And from the evil } \\
\text { of the envier when he envies" ,Thanks God, indeed I have to, any } \\
\text { way it's beyond repair. }\end{array}$ \\
\hline $\begin{array}{l}\text { Context of } \\
\text { situation }\end{array}$ & $\begin{array}{l}\text { The speech situation is at home. The mother is responding to the } \\
\text { dress incident that her daughter narrated. She quotes the proverb } \\
\text { affirming that surely the envious will suffer the consequences of } \\
\text { inflicting an evil ill eye on others. The mother expresses her } \\
\text { condemn by beseeching Allah' punishment to enviers. She asks her } \\
\text { daughter to get rid of the dress. The context communicates the } \\
\text { Hadith proposition. The proverb draws on the conventional word } \\
\text { qili:cah'meaning eradicates", though very brief and short the } \\
\text { proverb use expresses the reproachful speech event that is } \\
\text { equivalently articulated in the semantic content of the Hadith. }\end{array}$ \\
\hline Illocutionary act & $\begin{array}{l}\text { Direct: Assertive (Affirming) } \\
\text { Indirect: directive (Expressive/condemning) } \\
\text { Type of sentence and verb: Assertive -Passive } \\
\text { Complexity of structure: Simple }\end{array}$ \\
\hline $\begin{array}{l}\text { The related } \\
\text { Qur'an verse }\end{array}$ & 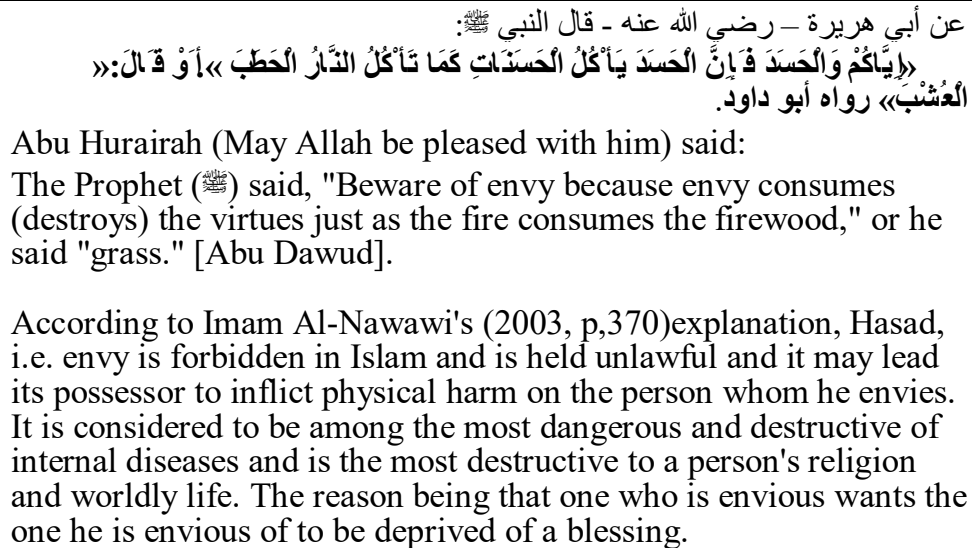 \\
\hline
\end{tabular}


Journal of English and comparative Studies

\section{Proverb Situation (5)}

\begin{tabular}{|c|c|}
\hline Source T & 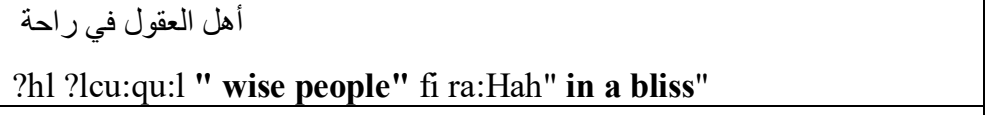 \\
\hline Target $\mathrm{T}$ & Wise people are in a bliss. (Wisdom is a bliss) \\
\hline Scene & $\begin{array}{l}\text { In the living-room, a son is expressing his wishes in the presence of } \\
\text { his father: } \\
\text { The son: I wish I could get rid of my car, so I could buy the car I drea } \\
\text { of } \\
\text { The father: Your car is already costing you a lot, think of fixing it } \\
\text { instead of replacing it. Indeed, " ?hl ?lcu:qu:l fi ra:Hah". } \\
\text { The son: I am thinking wise dad, See my old car is costing me more } \\
\text { money than a new one would. } \\
\text { The father: You are in a bliss, but not wise enough. }\end{array}$ \\
\hline $\begin{array}{l}\text { Context of } \\
\text { situation }\end{array}$ & $\begin{array}{l}\text { The speech situation is at home. The father utters the proverb } \\
\text { disapproving his son's silly wishes and stating that wealth and } \\
\text { acquisitive sprit don't provide peace of mind. The father starts } \\
\text { disapproving his son and urging to be sensible and assuring a } \\
\text { universal fact that thoughtfulness and wisdom is a bliss. By the end } \\
\text { of the conversation, he mocks the claim his son makes as "being } \\
\text { wise". The proverb communicates the semantic content of the verse } \\
\text { presented below and the direct speech that" Hikmah is indeed grants } \\
\text { abundant good". }\end{array}$ \\
\hline Illocutionary act & $\begin{array}{l}\text { Direct: Assertive (stating) } \\
\text { Indirect: Disapproving and mocking } \\
\text { Type of sentence and verb: Declarative -Active } \\
\text { Complexity of structure: simple }\end{array}$ \\
\hline $\begin{array}{l}\text { The related } \\
\text { Qur'an verse }\end{array}$ & 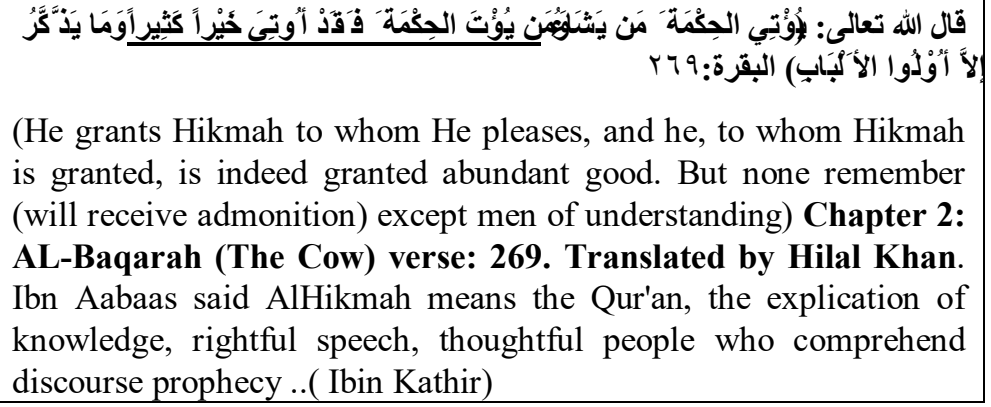 \\
\hline
\end{tabular}


Journal of English and comparative Studies

\section{Proverb Situation (6)}

\begin{tabular}{|c|c|}
\hline Source T & $\begin{array}{l}\text { الجوع يخلف الطبوع " الجوع:c " Hunger " yxlef" changes " ?Tbu:c " conduct and } \\
\text { manner" }\end{array}$ \\
\hline Target $\mathrm{T}$ & $\begin{array}{l}\text { Hunger changes man's behavior and conduct. (Hunger is the worst } \\
\text { enemy.) }\end{array}$ \\
\hline Scene & $\begin{array}{l}\text { The husband arrived home from work yelling at his wife: } \\
\text { The husband: haven't you prepared lunch yet?!! } \\
\text { The wife: what is wrong with you today? Get yourself busy until } \\
\text { lunch is ready, ?lju:c yexlef ?Tbu:c. }\end{array}$ \\
\hline $\begin{array}{l}\text { Context of } \\
\text { situation }\end{array}$ & $\begin{array}{l}\text { Home speech contex. The wife quotes this proverb to declare a } \\
\text { universal fact about the state of being hungry on the part of her } \\
\text { husband, she is expressing indirectly her annoyance of his behavior. } \\
\text { The proverb articulates the semantic content of the Hadith that } \\
\text { hunger is man's worst companion as it changes his behaviour. The } \\
\text { proverb directly expresses a universal observation about hunger. } \\
\text { Moreover, the proverb speech act of annoyance and displeasure of } \\
\text { huger is expressed in the semantic content of the Hadith. }\end{array}$ \\
\hline Illocutionary act & $\begin{array}{l}\text { Direct: Assertive } \\
\text { Indirect: Expressive of Annoyance } \\
\text { Type of sentence and verb: Declarative -Active } \\
\text { Complexity of structure: simple }\end{array}$ \\
\hline $\begin{array}{l}\text { The related } \\
\text { prophetic Hadith }\end{array}$ & 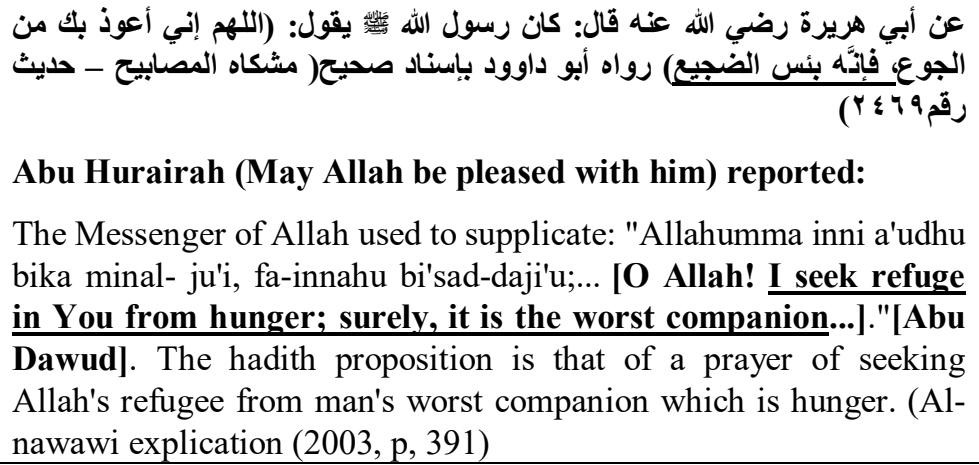 \\
\hline
\end{tabular}


Journal of English and comparative Studies

Proverb Situation (7)

\begin{tabular}{|c|c|}
\hline Source $\mathrm{T}$ & $\begin{array}{l}\text { قوت قوت لايموت } \\
\text { f" la yomou:t " so he would not die " }\end{array}$ \\
\hline Target $\mathrm{T}$ & Little foodstuff, What suffice him from dying. \\
\hline Scene & $\begin{array}{l}\text { At the dining room, the family is setting for the served lunch. } \\
\text { The son is hungry after school. } \\
\text { The son: Mom, rice and meat, I feel like devouring all dishes alone, } \\
\text { I am dying of hunger. } \\
\text { His mother: Oh, dear son, you should not. Qu:ot qu:ot la youmout. } \\
\text { East what suffice your stomach. } \\
\text { The son: Really hungry, mum. }\end{array}$ \\
\hline $\begin{array}{l}\text { Context of } \\
\text { situation }\end{array}$ & $\begin{array}{l}\text { The speech situation is at home. The mother is directly stating a } \\
\text { worldly contention that one eats what suffice him and directing her } \\
\text { son to be moderate and average. The proverb directly and clearly } \\
\text { states and direct the behavior accounting on a general truth } \\
\text { expressed in relation to the culturally specific proverb that } \\
\text { compromise conventional classical wording of qu:ot, meaning what } \\
\text { sustains one from dying. The context of situation and the pragmatic } \\
\text { skill of the mother in quoting an appropriate proverb in the speech } \\
\text { situation of hunger enforce the performance of the speech act of } \\
\text { directing the behavior of her son. The proverb and Hadith } \\
\text { communicate the indirect speech act of direction and } \\
\text { recommending. }\end{array}$ \\
\hline Illocutionary act & $\begin{array}{l}\text { Direct: Assertive stating and boasting } \\
\text { Indirect: Directive (recommending) } \\
\text { Type of sentence and verb: Imperative -Active } \\
\text { Complexity of structure: simple } \\
\text { Assonance of repeated words that adds rhyme: Qu:ot qu:ot la } \\
\text { youmou:t }\end{array}$ \\
\hline $\begin{array}{l}\text { The related } \\
\text { prophetic Hadith }\end{array}$ & 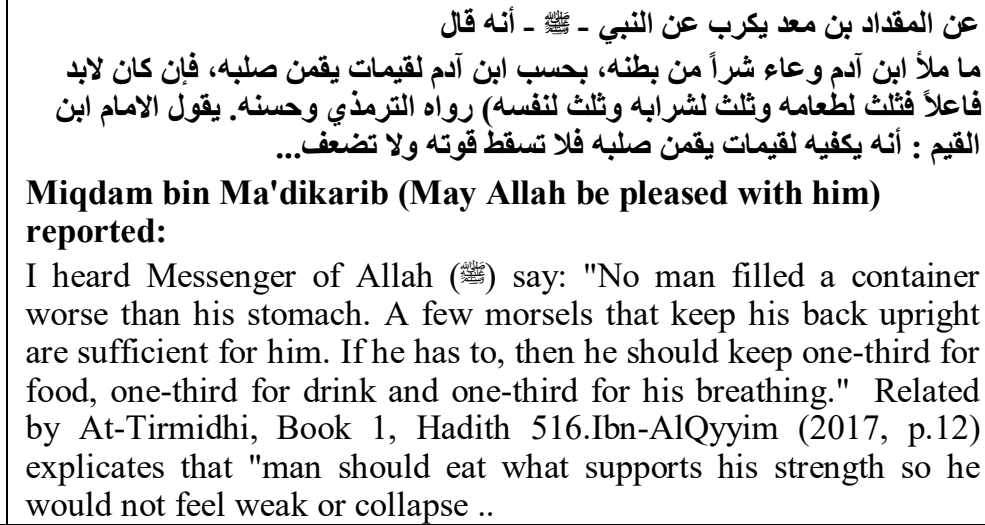 \\
\hline
\end{tabular}




\section{$\underline{\text { Proverb Situation (8) }}$}

\begin{tabular}{|c|c|}
\hline Source T & $\begin{array}{l}\text { ترزق بلاد الفسد ولا ترزق بلاد الحسد "thee corrupted country " } \\
\text { Tourzq "thee bestows" bilad alfasad "the } \\
\text { wala tourzq bilad alHasad " and not the envious country " }\end{array}$ \\
\hline Target $\mathrm{T}$ & $\begin{array}{l}\text { The proverb echoes the sense that "The corrupted city is rewarded, } \\
\text { the envious city is denied " and the English proverb " Envy is a } \\
\text { sin". }\end{array}$ \\
\hline Scene & $\begin{array}{l}\text { A conversation is running between a mother and her daughter } \\
\text { discussing a relative daughter who won a gold prize in a contest. } \\
\text { The mother: I heard that your aunt won a prize at a contest? } \\
\text { The daughter: Mom, my aunt is not that brilliant, I wonder how she } \\
\text { won that prize?! } \\
\text { The mother: They were right when they said, Tourzq bilad } \\
\text { alfasad, wala tourzq bilad alHasad, you shouldn't say that. } \\
\text { The daughter: I seek God's Forgiveness, reall, I didn't mean any } \\
\text { harm. }\end{array}$ \\
\hline $\begin{array}{l}\text { Context of } \\
\text { situation }\end{array}$ & $\begin{array}{l}\text { The speech situation takes place at home. The mother utters the } \\
\text { jealous and envious proverb to clarify and state to her annoyed, } \\
\text { daughter that God recompenses those who are not envious of others } \\
\text { even if they are but not those who are green with envy. The mother } \\
\text { is disapproving her daughter negative feelings and that God } \\
\text { rewards those who have well intensions even if they are } \\
\text { mischievous. The daughter apprehends the speech event and } \\
\text { rephrases her stand by saying "I didn't mean harm". The proverb } \\
\text { syntactic structure of contrasted verb phrases intensifies its } \\
\text { semantic content. The proverb and Hadith articulate the direct } \\
\text { speech act of asserting and the same semantic proposition that envy } \\
\text { eradicates. }\end{array}$ \\
\hline Illocutionary act & $\begin{array}{l}\text { Direct: Assertive / stating } \\
\text { Indirect: Expressive(disapproving) } \\
\text { Type of sentence and verb: Declarative -Active } \\
\text { Complexity of structure: Contrasted verb phrases (syntactic } \\
\text { repletion) to emphasize the overall meaning of the proverb. }\end{array}$ \\
\hline $\begin{array}{l}\text { The related Qur'an } \\
\text { verse }\end{array}$ & 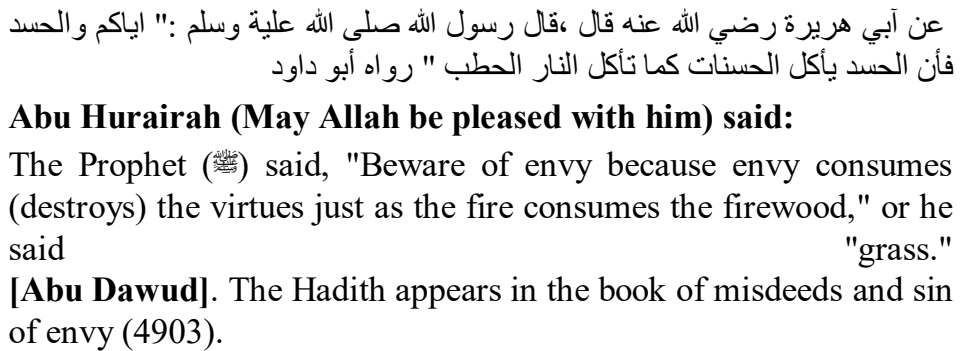 \\
\hline
\end{tabular}


Proverb Situation (9)

\begin{tabular}{|c|c|}
\hline Source T & $\begin{array}{l}\text { ما يخلق شدق الا وله رزق } \\
\text { ma: yexleq Jedq " no mouth is created " ila wluh rizq " unless it } \\
\text { is provided for" }\end{array}$ \\
\hline Target $\mathrm{T}$ & $\begin{array}{l}\text { Every mouth is provided for, (every creature livelihood is sustained } \\
\text { by God) }\end{array}$ \\
\hline Scene & $\begin{array}{l}\text { A conversation is running between a mother and her daughter } \\
\text { discussing family issues. The speech situation is at home. } \\
\text { The daughter. Mum, I don't know how my sister is going to handle } \\
\text { one more child, aren't four kids enough? } \\
\text { The mother: What comes from Allah is welcomed. ma: yexleq } \\
\text { fedq. } \\
\text { The daughter: ila wluh rizq, I know that for sure. }\end{array}$ \\
\hline $\begin{array}{l}\text { Context of } \\
\text { situation }\end{array}$ & $\begin{array}{l}\text { The speech situation is at hom. The sister is lamenting the } \\
\text { situation of her sister who is having four kids and turned to be } \\
\text { pregnant, the mother state that this is God's will, and directs her } \\
\text { daughter to articulates thankfulness and submissiveness to God's } \\
\text { will. The daughter speech turn indicates mutual communication of } \\
\text { the proverb. This bears to the fact that Al-Bahah speakers share the } \\
\text { same cultural norms of communication when it comes to proverb } \\
\text { articulation. The mother skillfully draws analogy between the } \\
\text { speech event and the performativity of the proverb quoted. }\end{array}$ \\
\hline Illocutionary act & $\begin{array}{l}\text { Direct: Asserting: (stating) } \\
\text { Indirect: Declarative: (submissive) } \\
\text { Type of sentence and verb: Declarative -Active } \\
\text { Complexity of structure: complex (Clefting and foregrounding of } \\
\text { the adverbial phrase) }\end{array}$ \\
\hline $\begin{array}{c}\text { The related Qur'an } \\
\text { verse }\end{array}$ & $\begin{array}{l}\qquad \text { " ما من دابة في الأرض الا على الله رزقها" ( سورة هود . (ايه V) } \\
\text { (And no moving (living) creature is there on earth but its provision } \\
\text { is due from Allah) Chapter11, Hud.Verse 7. } \\
\text { Ibn Kathir explicated that there is no moving creature on the earth } \\
\text { but that upon Allah is its provision and sustenance. (p. 222) }\end{array}$ \\
\hline
\end{tabular}




\section{Proverb Situation (10)}

\begin{tabular}{|c|c|}
\hline & $\begin{array}{l}\text { ?rqu:d " sleep" da:fi " heartfelt ,tight and warmhearted "teSbh } \\
\text { metca:fi" wakes up sound" }\end{array}$ \\
\hline Target $\mathrm{T}$ & $\begin{array}{l}\text { Sleep heartfelt (content) and you will wake up feeling healthy } \\
\text { and vigorous }\end{array}$ \\
\hline Scene & $\begin{array}{l}\text { The speech situation comprises a father who sent his son to } \\
\text { withdraw an amount of money from cash machine, the ATM } \\
\text { cashed money before he insert the card. The son overwhelmingly } \\
\text { happy and narrates the incident to all. } \\
\text { The son: I acquired money from God, the ATM seems to be out } \\
\text { of order and cashed me } 500 \text { riyals, before I even insert your card. } \\
\text { The father: What is in your mind son? } \\
\text { The son: I think I earned it and any way the bank wouldn't know. } \\
\text { The father: This is unlawful, and God forbids, ?rqu:d da:fi } \\
\text { teSbh metca:fi.You better return the money to the bank, before } \\
\text { its owner claim it. }\end{array}$ \\
\hline Context of Situation & $\begin{array}{l}\text { The father utters the proverb as an immediate response to his } \\
\text { son's that the money he found is his own, asserting the belief that } \\
\text { enjoying a peaceful and content life is the real wealth and not any } \\
\text { unrightfully action. The father is motivating his son to do what is } \\
\text { right (retuning the money) and warning (someone will claim the } \\
\text { money). By competently quoting this proverb, the father is } \\
\text { performing indirectly the act of warning employing a prover } \\
\text { construction of reason-result to enforce that safety leads to } \\
\text { happiness. The proverb and Hadith share equivalent semantic } \\
\text { proposition " waking up safe and sound makes one seizes worldly } \\
\text { happiness. }\end{array}$ \\
\hline IIlocutionary act & $\begin{array}{l}\text { Direct: Assertive } \\
\text { Indirect: Directive (motivating/warning) } \\
\text { Type of sentence and verb: Imperative-Active } \\
\text { Complexity of structure: parallel structure of similarity between } \\
\text { the first and second phrases. }\end{array}$ \\
\hline $\begin{array}{l}\text { The related } \\
\text { prophetic hadith }\end{array}$ & 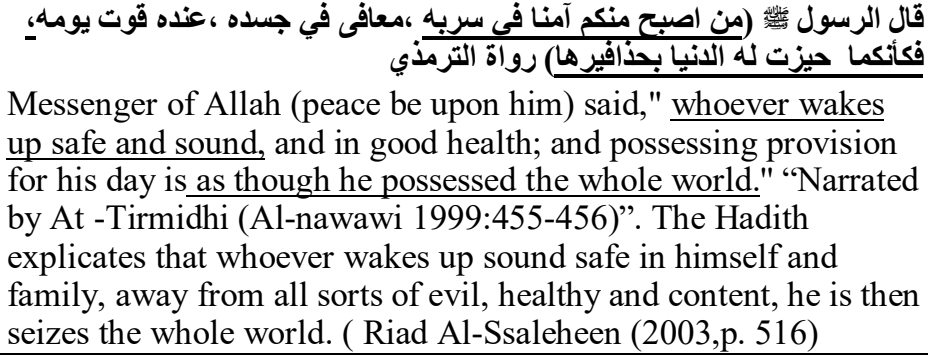 \\
\hline
\end{tabular}




\section{Proverb Situation (11):}

\begin{tabular}{|c|c|}
\hline Source T & $\begin{array}{l}\text { حبة مع حبة تكيل وقطرة مع قطره تسيل } \\
\text { Haba maca Haba teki:1" a seed with a seed adds weight " wa qaTra } \\
\text { Mca qaTra tsi:l" a drop with a drop makes a stream " }\end{array}$ \\
\hline Target $\mathrm{T}$ & $\begin{array}{l}\text { One seed with another adds weight and one drop with another make a } \\
\text { stream. The proverb articulates the sense "one hand cannot clap" }\end{array}$ \\
\hline Scene & $\begin{array}{l}\text { In the living-room a mother is asking her daughter to help her cleaning } \\
\text { one of the rooms: } \\
\text { The mother addressing her daughter: Listen today we have lots of work } \\
\text { to do, all the needless summer clothes need to moved, have'nt you } \\
\text { heard " Haba maca Haba teki:I, wa qaTra Mca qaTra tsi:I" } \\
\text { The daughter: I have not actually, but I got what you mean. }\end{array}$ \\
\hline $\begin{array}{l}\text { Context of } \\
\text { Situation }\end{array}$ & $\begin{array}{l}\text { Domestic speech situation. The mother utters the proverb stating that } \\
\text { individual effort may not be as fruitful as collaborative effort and thus } \\
\text { estimating co-operation and group working. By doing so, indirectly she } \\
\text { motivates herself and her daughter to attend to work. The speech event } \\
\text { accommodates for the collective agents (the mother and daughter). The } \\
\text { proverb and Hadith communicate the same semantic proposition } \\
\text { expressed in the proverb. }\end{array}$ \\
\hline $\begin{array}{l}\text { Illocutionary } \\
\text { act }\end{array}$ & $\begin{array}{l}\text { Direct: Assertive(stating) } \\
\text { Indirect: Directive (motivating) } \\
\text { Type of sentence and verb: Declarative-Active } \\
\text { Complexity of structure: paratactic structure of equality or similarity } \\
\text { between the first and second phrases }\end{array}$ \\
\hline $\begin{array}{l}\text { The related } \\
\text { Hadith }\end{array}$ & 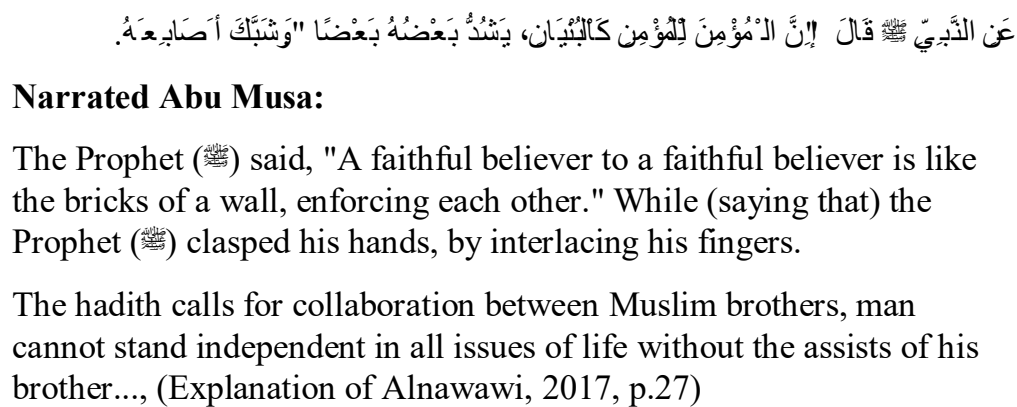 \\
\hline
\end{tabular}




\section{Proverb Situation (12)}

\begin{tabular}{|c|c|}
\hline Source T & $\begin{array}{l}\text { إنلف والله يخلف (tlef (expend and consume) wa Allah Yexlef (recompenses ) } \\
\text { ?the }\end{array}$ \\
\hline Target $\mathrm{T}$ & $\begin{array}{l}\text { The proverb communicates that whatever you spend and exhaust for } \\
\text { others, God will reward and repay you. The proverb communicates the } \\
\text { wisdom of generosity, No English proverb reflects the source proverb. }\end{array}$ \\
\hline Scene & $\begin{array}{l}\text { Eid Al-Ftir speech situation. (The celebration after the break of fasting } \\
\text { the Holy Month of Ramadan) g, the host served lunch and invited the } \\
\text { local community and neighbours for the feast. The following dialogue } \\
\text { runs between three participants: } \\
\text { Speaker1: Masha Allah, the smell is captivating. } \\
\text { Speaker 2: Indeed, Maha (the host). It seems you have spent all day in } \\
\text { the kitchen, these dishes must have cost you a fortune. } \\
\text { Maha: Delighted dearest, Not at all, May Allah accepts my goodwill, } \\
\text { "expense and Allah will recompense", It is Eid day and I am pleased that } \\
\text { people come for the feast. }\end{array}$ \\
\hline $\begin{array}{l}\text { Context of } \\
\text { Situation }\end{array}$ & $\begin{array}{l}\text { The host responds to the positive remarks of feast by assuring her duty } \\
\text { as a host to be generous and implicitly committing herself to the } \\
\text { religious belief that Allah rewards those who commit themselves with } \\
\text { good intensions of charity to others. The proverb pragmatically fits the } \\
\text { situation as the host assures the speech participants of Allah' generous } \\
\text { rewards for benevolence and generosity as motivated by Islamic } \\
\text { religious wisdom. The proverb and Hadith are declarative and share the } \\
\text { same semantic proposition. }\end{array}$ \\
\hline $\begin{array}{l}\text { Illocutionary } \\
\text { act }\end{array}$ & $\begin{array}{l}\text { Direct: Expressive :(assuring) } \\
\text { Indirect: Declarative :( Committing) } \\
\text { Type of sentence and verb: Declarative - Active } \\
\text { Complexity of structure: simple }\end{array}$ \\
\hline $\begin{array}{l}\text { The related } \\
\text { Qur'an verse }\end{array}$ & 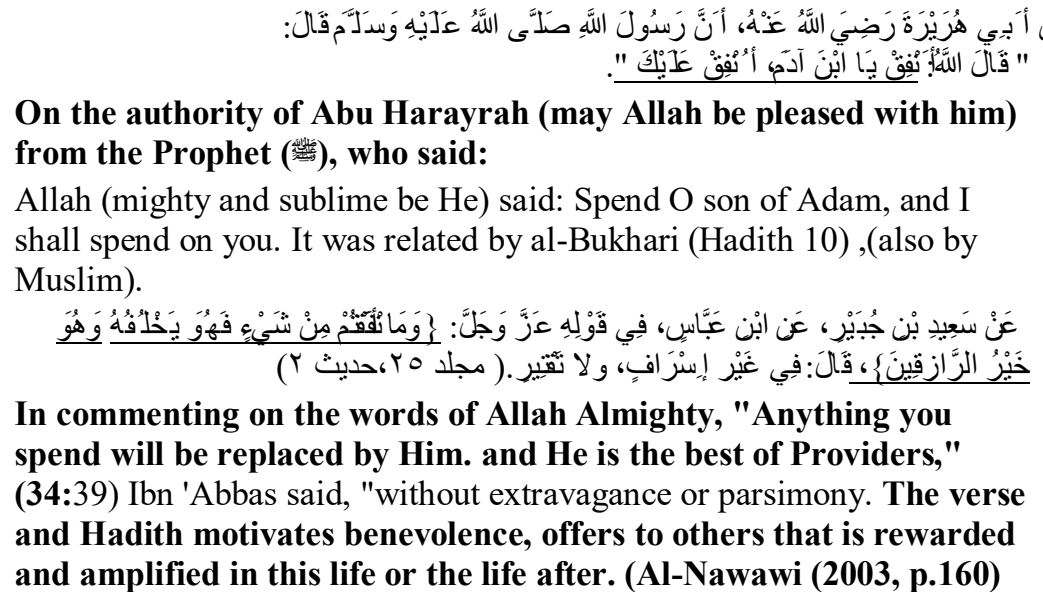 \\
\hline
\end{tabular}


Journal of English and comparative Studies

\section{Proverb Situation (13)}

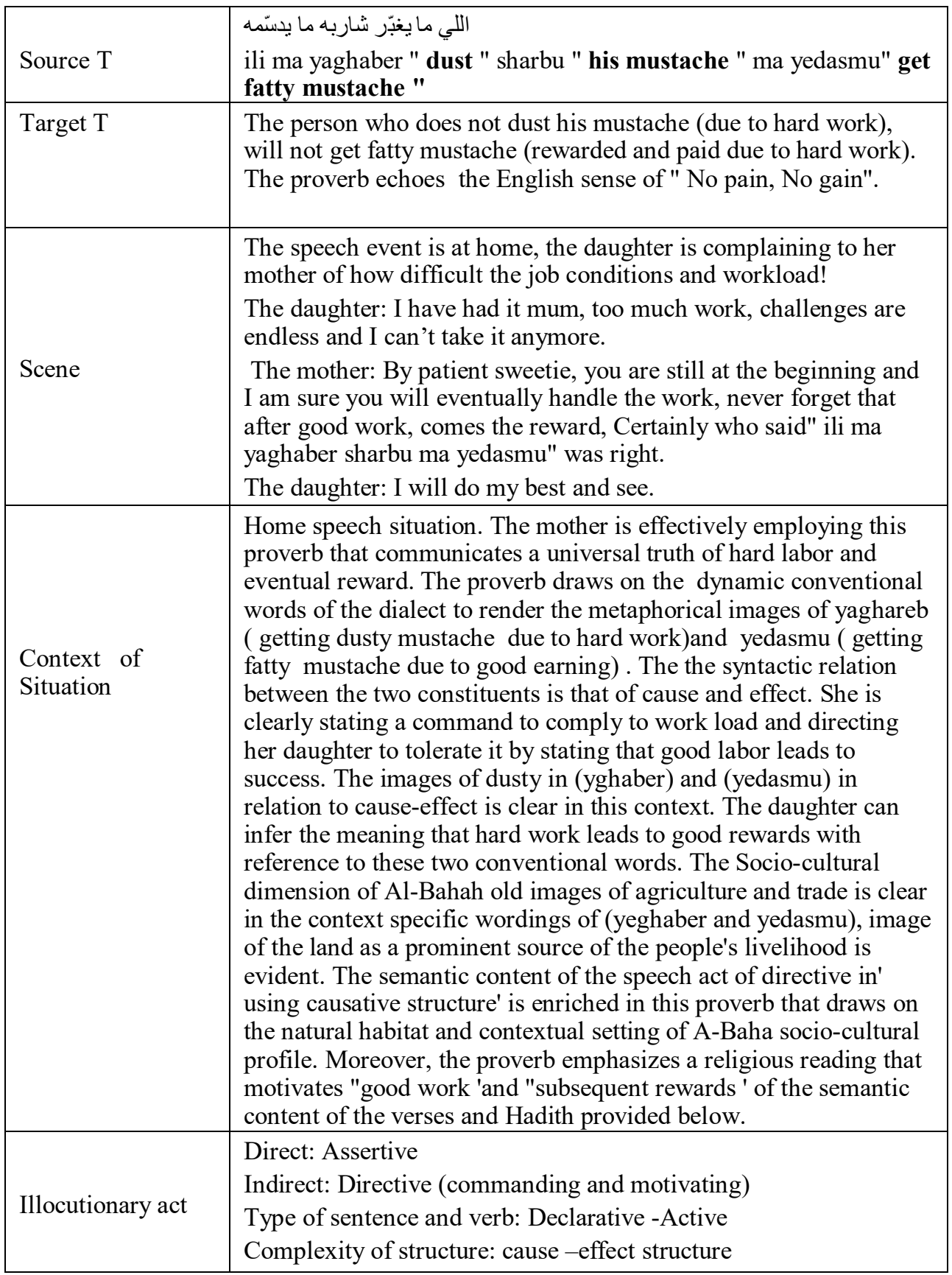


Journal of English and comparative Studies

\begin{tabular}{|c|c|}
\hline $\begin{array}{l}\text { The related Qur'an } \\
\text { verse }\end{array}$ & 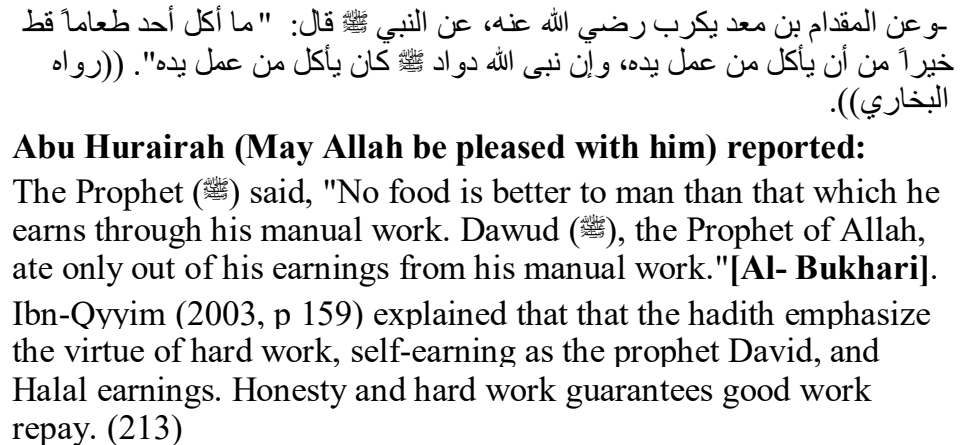 \\
\hline
\end{tabular}

\subsubsection{Discussion of Data}

To conclude, this paper aimed at highlighting the sociolinguistic proverbial scene of Al-Bahah Province by applying a speech acts theory. The data revealed the followings:

Al-Bahah proverbs represent different social and cultural beliefs and values framing the community's whole life. Their positive views concerning issues such as values, beliefs, domestic life, adhering to morals and abandoning misdeeds originally spring from true religious principles. Thereupon, it could be deduced that they constitute not only a culturalspecific linguistic genre but also a religious one.

- The attribution of a proverb to a certain speech act is not clear-cut, the meaning of a proverb can be modified and even reversed in different situations. So different conversational contexts of situations can lead to different speech acts. Context of situation, pragmatic fitness of the old speakers of the dialect play a significant role in speech act performance.

- Assigning a Qur'anic verse or related Hadith to the propositional content or the speech act the proverb performs in the conversational context was a challenge. Yet, it reveals how far religion penetrates in every day conversational contexts and how far proverbial utterances that accomplished illocutionary acts and brings Al-Bahah proverbs to life ' in the apparent time".

- Generally speaking, Al-Bahah Proverbs have multiple-indirect illocutionary acts by means of a single act. That explains why the indirect acts $(69.2 \%)$ have a higher percentage than the direct ones $\mathbf{( 3 0 . 8 \% )}$.

- In regard to direct acts, the assertive act has scored the highest percentage of the other five illocutionary speech acts, this score leads us to say that Al-Bahah Proverbs are emphatically assertive rather than declarative or imperative in structural terms. The declarative act is the second prominent direct act, then comes the directive-expressive and assertive-declarative are of equal score. No commissive or expressive direct speech acts in Al-Bahah proverbs because they reflect established forcefully point of view about beliefs, attitudes and feelings.

- The declarative speech act is the most prominent indirect act in the proverbial conversations, (declaratives scored $38.4 \%$ ).In short, Al-Bahah community tend to proclaim, announce and assert their views. The directive speech act records second score in the data ( $\mathbf{3 0 . 8 \% )}$ ).It seems that $\mathrm{Al}-\mathrm{Bahah}$ speech community apt to advice, urge motivate, warn, and threaten indirectly rather than directly. This indirect implicit speech act reflect politeness as people usually try to be indirect when directing others and not explicitly in order not to make others feel controlled, belittled or 
offended. The expressive indirect speech act records second then the assertive speech acts, it could be said that the speech community of Al-Bahah like to discuss, express and talk about their attitude over certain good deeds and misbehaviors. They skillfully accomplish the goal by means of the indirect expressive act.

- Though proverbs may be viewed as forms of traditional oral art, Al-Bahah proverbs operate effectively due to the performative proposition the proverb expresses and their relevance to the context of the speech situation. The religious dimension of language use can be traced in current every day conversations, yet employing proverbs that draw on religious values reflect the pragmatic aptness of the speech community to relate to the wisdom of the past. Viewing the background of AlBahah in the past years, it could be deduced that proverbs were actually formulated by uneducated people, and at an era when education had not received much attention. Al-Bahah people have proved to be conscious of their religious beliefs and concepts; the result that is achieved through the analysis provided in the study where 13 proverbs have proved to be relevant to a single prophetic Hadith or a Qur'anic verse.

- The active voice is overwhelmingly used and the use of passive constructions is almost nil (only in 2 proverbs).

- Al-Bahah proverbs structure is of simple structure as short proverbs generally concise and memorable.

- Al-Bahah proverbs are realized in different syntactic structures. Six proverbs are of simple structure (SVP), the structure of reason-result is recorded in three proverbs, paratactic structures of equality or causticity between phrases recorded two proverbs, one proverb of a parallel verbal phrase, and only one complex proverb of contrastive verb phrases (clefting). Generally speaking, Al-Bahah proverbs are of moderate level of complexity.
- The most prominent theme recorded in Al-Bahah proverbs relates to (?lju:c, qu:ot , ?1Hab,qaTra, rizq )respectively hunger, feed, drop, livelihood ) which denote to earlier urgent needs and prerequisites of survival. Such concerns are employed in their proverbs, though life conditions currently changes to the good, yet these proverbs are still recalled due to the positive didactics they hold in Islam.

- Al-Bahah speech community tend to use simple parallel structure in some proverbs (eight proverbs record parallel structures at word or clauses level), parallel structure makes it is easy to memorize proverbs and recites them حبة مع whenever it is appropriately as in Haba maca Haba tse:1 wa qaTra Mca qaTra tse:1 ). Parallel structure is not haphazardly used for simplicity, but rather for enriching the meaning and stressing a specific moral.

- Though brevity characterizes most of Al-Bahah proverbs, some of these proverbs are somewhat long. Long proverbs usually include descriptive or evaluative statements.

\subsection{Conclusion}

The study comes to the conclusion that AlBahah proverbs are representatives of broader socio cultural wisdoms inherent in the speaking community, and are therefore weighted not only with the social and cultural implications, but also with religious ones. Al-Bahah speech community reveals pragmatic fitness in employing performative proverbs in specific contexts of situations and that these proverbs correspond either in their semantic content or the speech act they communicate to Qur'anic verse or prophetic Hadith. The findings of the study could be further be supported by larger data qualitatively and quantitatively. 


\section{References}

Abdul Jabbar, L.R (2008). A linguistic Analysis of the Speech Act of Advice in American English Proverbs. UIuc, Vol.19 (1).

Bu Zerr Maher. (2004). Ideological Errors in Palestinian Proverbs, Structures, and Popular Habits. MA Thesis submitted to Gaza Islamic University.

Adeeko, A. (2016). Arts of Being Yoruba: Divination, Allegory, Tragedy, Proverbs. Panegyric. Indiana University Press.

Al-Nawawi, A, (2003) Riyad Al-Saleheen: min Kalaam Sayeid Almursaleen. Al-Maktabah Al-aSri:yah. Beirut.

Al-Sohaibani, Ali. (2017). Influence of religion on language use: A Socio-pragmatic study on the influence of religion on speech acts performance. University of East Anglia. UEA, prints AC. UK.

Ashipu, K.B.C (2013). Proverbs as Circumstantial Speed acts Journal of Humanities and Social Sciences, Vol 3, N.7, P.P. 10.15)

Alsalouk, Ali. (1994). Almawrouthat Alsh'beiyah le Ghamid wa Zahran: The Fifth series of Al-Amthal. Riyadh: King Fahad National Library.

Al-Saadi, W.M. (2009). A sociolinguistic Study of Relgious-Based Makkan Proverbs. M.A. Thesis submitted to the Dept. of English in Girls' College of Education, Makkah, Um Al-Qura University.

Austin, J.L. (1962). How to do things with words. London: Oxford University Press.

Ayeni, G. O. (2011) A Pragmatic Analysis of Nigerian Proverbs in Wole Soyinka's the Lion and the Jewel. Published Bachelor of Arts Thesis. Faculty of Arts, University of Ilorin, Nigeria.

Coinnigh, M. (2015). Structural Aspects of Proverbs. Walter de Grunter GMBh, (eds)

Fairclough, N. (1992). Discourse and Social Change, Cambridge: Polity Press. MA

Geis M., L. (1995). Speech Acts and Conversational interaction: Toward a theory of conversational Competence. Cambridge and New York: Cambridge University Press.

Holes, C. (1984). Colloquial Arabic of the Gulf and Saudi Arabia. London: Routledge and Kegan Paul.

Hymes, D and Gumpertz, J. (1991) Directions in Sociolinguistics: The Ethnography of Communication Wiely-Blackwell, London

Ibn Al-Qyyim, M. I. (2010) Tafsir The Glorious Qur'an for Ibn Al-Qyyim 691-751). First Edition. Dar Wa Maktabat Alhilal.Beirut.

Ibn Kathir, A A. A. (2011). Tafsir Ibn Kathir.Series 1-5. Dar -AL-Kitab AlArabi, Beirut, Lebanon. 
-The Tafsirs. On-line Site maintained by Royal Aal Al-Bayt Institute. https://WWW.aalalbayt

Ing̈ham, B., (1982). North-East International dialects. London: Kegan Paul International.

Jinadu, L.N (2017) The Socio-Cultural Construction of Intertextuality Through Proverbs: A Universalist Conceptualist Study of Arabic-Yoruba proverbs. Academia.edu (Internet accessed at 22-Nov.-20170

Labov, W. (1972). Language in the Inner City: Studies in the Black English Vernacular. Philadelphia: University of Pennsylvania Press.

Lamidi, Mufutan, T. (2008). The Structure and Texture of English Translations of Yoruba and Igbo Proverbs. Journal of Language \& Translation9-1,61-90

Lawal, A. \& et.al (1997) "A Pragmatic Study of Selected Pairs of Yoruba Proverbs". Journal of Pragmatics, 199705.

Leech, G. (1989). Principles of Pragmatics. London: Longman.

Levinson, Stephen. (1983). Pragmatics. Cambridge University Press, Cambridge, UK

Martin, Gary (2015). Meaning and Origins. In The Phrase Finder Online Resource: http://www.phrase.org.uk/meanings/proverbs.html [last visited: 13 June 2015].

Mieder, Wolfgang (2004) Proverbs: A Handbook. Greenwood Folklore Handbooks. United states.

Mesthrie, R., (ed.) (2001). Concise encyclopedia of Sociolinguistics. Oxford: Pergamon Press.

Mey, Jacob. (2001). Pragmatics: An Introduction. Oxford: Blackwell Publishing.

Nadawi, Abdullah, Abbas (1968) A study of the Arabic Dialect of the Belad Ghamid and Zahran Region of Saudi Arabia on the Basis of Original Field Recording and an Examination of the Relationship to the Neighboring Regions. A Thesis submitted to the University of Leeds.

Norrick, N.R. (1991). 'One is none': Remarks of Repetition in Proverbs. Proverbium: Yearbook of International Proverb Scholarship 8,121-128.

Ramirez, Christina, H. (2015). A Pragmatic approach to proverb use and interpretation. Faculted De FilosofiamY letras

Robins, R. (1980). General Linguistics . $3^{\text {rd }}$ ed. Longman Group Ltd.

Searle, John. (1979). Expression and Meaning: Studies in the Theory of Speech Acts. Cambridge, England: Cambridge University.

Searle, R. (1969). Speech Acts. Cambridge: Cambridge University.

Sperber, Dan Wilson, D. (1995). Relevance- Communication and Cognition $.2^{\text {nd }}$ Ed. Blackwell, Oxford UK and Cambridge University.

Spolsky, B., (1998). Sociolinguistics. London: Oxford University Press. 
Sunnah.com ( Hadith of the Prophet Muhammad (pbuh) in several languages. Retrieved from http://lucene.apache.org./core/download.html

Institute for Islamic Thought. Retrieved from http://WWW..aalalbayt.org, Last accessed at 2018.

Thomas, J (1995). Meaning in Interaction: An Introduction to Pragmatics. London and New York: Longman.

Trask, R., (1996). Historical Linguistics. London: Arnold.

. (1999). Key concepts in Language and Linguistics. London: Routledge.

Wardhaugh, R. (2002). An Introduction to Sociolinguistics . $4^{\text {th }}$ ed. Oxford: Blackwell. 